\title{
DECREASE OF BEARING CAPACITY DUE TO ADJACENT EXCAVATION
}

\author{
By Yorihiko OHSAKI*, \\ Akio HARA**
}

\section{§ 1 INTRODUCTION}

If the ground adjacent to a footing or a structure is excavated as shown in Fig. 1, it is evident that bearing capacity of the soil beneath the footing or the structure will be decreased to a certain extent. It is anticipated that the rate of decrease will be affected by the width $B$ and the depth of embedment $D$ of the footing or the structure, the distance to the excavation $S$, the depth $H$ and the width $L$ of the excavation and the properties of

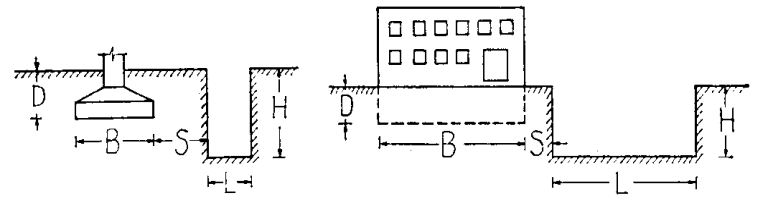

Fig. 1 the subsoil, i.e., its unit weight $r$, cohesion $c$ and angle of internal friction $\phi$.

The purpose of this paper is to present a digital computer program, by means of which the decrease of bearing capacity due to adjacent excavation can be evaluated approximately under the assumption of circular sliding surface.

\section{§ 2 FEATURES OF SLIDING SURFACE}

For the simplicity of analysis the following assumptions will be made in this paper :

(1) The problem is dealt with two-dimensionally.

(2) The unit weight of soil $r$ is uniform in the entire mass; the cohesion $c$ and the angle of internal friction $\phi$ are also constant.

(3) The sliding surface is circular, which passes through the edge of the loaded area opposite to the excavation.

(4) The resistance of the soil along the sliding surface is mobilized in such a way that has already been described in the previous paper ${ }^{1}$.

The coordinates $X$ and $Z$ are taken such that the axis $X$ lies on the ground surface and the axis $Z$ passes through the midpoint of the loaded area, and with respect to these coordinates the center of the sliding circle is assumed to be located at $\left(X_{0}, Z_{0}\right)$.

According to the location and the dimensions of the excavation we can now distinguish four features of the sliding circle as shown in Fig. 2. Namely :

Circle I : The sliding surface intersects with the ground surface at a location between the loaded area and the excavation.

Circle II : The sliding surface intersects with the nearer wall of the excavation.

Circle III : The sliding surface intersects with the bottom of the excavation.

Circle IV : The sliding surface intersects with

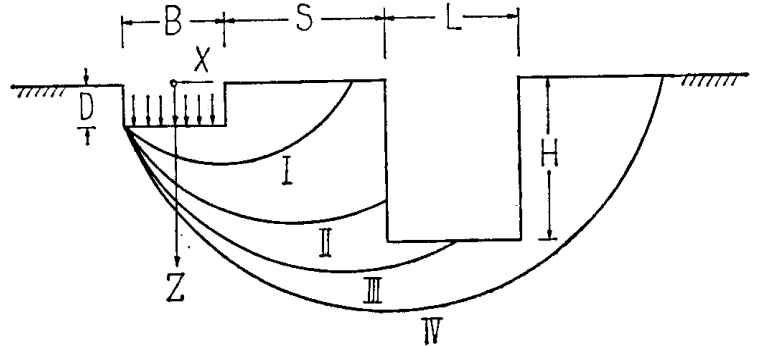

Fig. 2 the ground surface at a location beyond the excavation and the excavated area is entirely included within the sliding circle.

Analytical expressions for each of these four features are summarized in Table 1, in which

* Building Research Institute, Ministry of Construction, Japanese Government. Member of A.I.J.

** Institute of Construction Technology, Kajima Construction Co. Member of A.I.J. 


$$
\begin{aligned}
& R=\sqrt{\left(\frac{B}{2}+X_{0}\right)^{2}+\left(D-Z_{0}\right)^{2},} \\
& S_{x}=\frac{B}{2}+S-X_{0} \\
& T=\sqrt{R^{2}-Z_{0}^{2}} \\
& U=\sqrt{R^{2}-\left(H-Z_{0}\right)^{2}}
\end{aligned}
$$

It is evident that, among the values of $q$ determined from the equilibrium of overturning moments and resisting moments with respect to different locations of the center of circular sliding surface, $\left(X_{0}, Z_{0}\right)$, for given values of $B, D, S, H, L, r, c$ and $\phi$, the minimum gives us the bearing capacity in question for the given case.

\section{§ 3 DIGITAL COMPUTER PROGRAM}

In APPENDIX a digital computer program for evaluating the decreased bearing capacity is shown in ALGOL language. As in the case of the previous paper ${ }^{1)}$, the computer first locates the center of the sliding surface at different grid-points of a large grid and then, by contracting the grid step by step, the accuracy is improved until practically sufficient approximation of the required bearing capacity value is reached. In the program the description of the procedures labelled SIGMA and MINIMUM is omitted since they are completely same as what have been shown in the previous paper ${ }^{1)}$. It should also be noted that, in the program, the lengths $S$, $H, L, D$ are divided by $B$, and the cohesion $c$ and the pressure $q$ are divided by $r B$ to express them in dimensionless form.

\section{§ 4 NUMERICAL EXAMPLE}

Suppose a building of width $B$ with a raft foundation at the level of $D / B=0.4$ has been built on the uniform mass of soil with cohesion $c / r B=$ 0.5 and angle of internal friction $\phi=30^{\circ}$, and now we compute the rate of decrease of bearing capacity $Q / Q_{0}$ when an excavation having the width $L / B=1.0$ is made with varied depths $H / B=0 \sim$ 2.0 at the various distances $S / B=0 \sim 3.0$, whereas $Q_{0}$ means the bearing capacity without any effect of excavation.

The result of comptation is as shown in Fig. 3 , in which the domains for respective features of sliding circle are also designated.

\section{REFERENCE}

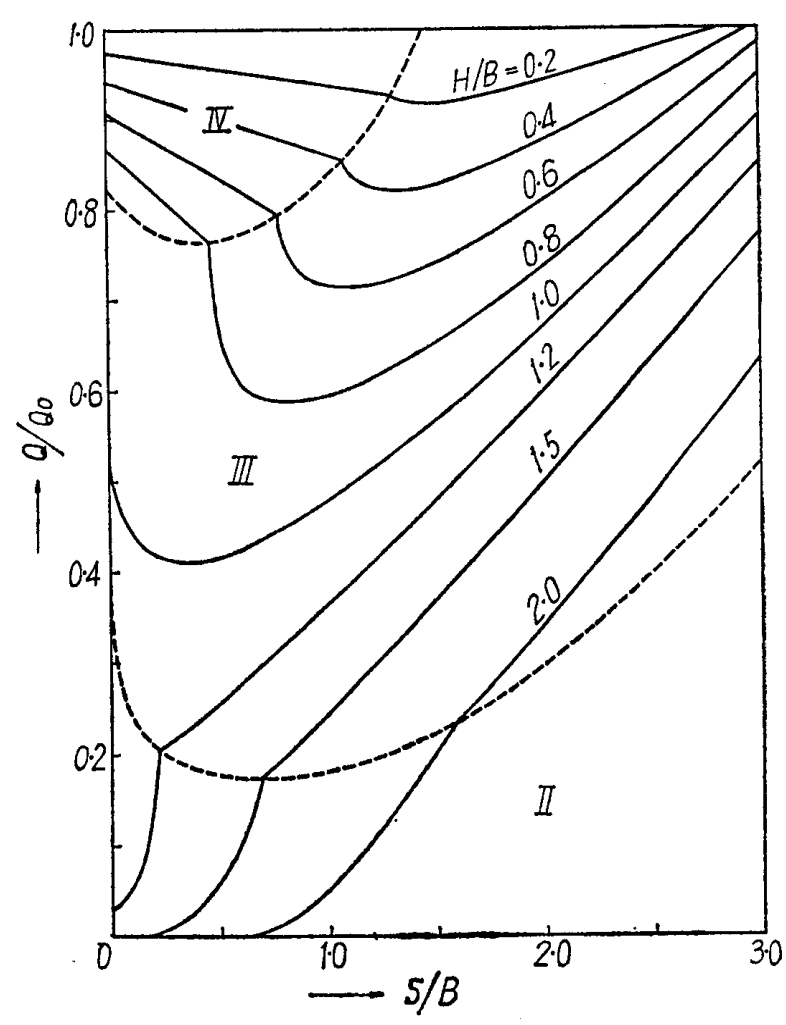

Fig. 3

1) Ohsaki, Y.: An Approximate Solution to Bearing Capacity Problem of Two-Layered Subsoil, Transactions of the Architectural Institute of Japan, No. 99, June 1964

\section{APPENDIX}

begin real S, H, L, D, C, PHI, K0, TANP, XM, ZM, MESH, QMIN, XQMIN, ZQMIN; integer $\mathrm{K}$, LABMIN;

START) begin READREAL(S) ; READREAL(H) ;READREAL(L) ;READREAL(D) ; READREAL(C); READREAL(PHI) ; READREAL(KO); CRLF ; CRLF ; CRLF ; PRINTSTRING(S); PRINTREAL(S) ; PRINTSTRING(H) ; PRINTREAL(H) ; PRINTSTRING(L); PRINTREAL(L); PRINTSTRING(D); PRINTREAL(D) ; CRLF ; PRINTSTRING(C); PRINTREAL(C); PRINTSTRING(PHI); PRINTREAL(PHI); PRINTSTRING (K0); 
PRINTREAL (K0); PHI : =0.0174533*PHI ; TANP : $=\operatorname{SIN}(\mathrm{PHI}) / \mathrm{CŌS}(\mathrm{PHI}) ; \mathrm{K}:=\mathbf{3}$; $\mathrm{XM}:=1.5 ; \mathrm{ZM}:=-1.0 ; \mathrm{MESH}:=0.2 ; \mathrm{QMIN}:=100000.0$; end START;

CYCLE) $\mathrm{K}:=\mathrm{K}-1$;

LŌCATE) begin real X0, Z0, R 2, R, T, I, J, Q;

procedure QCŌMP :

begin real X 1, X 2, Z 1, DELTA, XT, SX, U, W 1, W 2; integer LABEL; procedure SIGMA :

$\mathrm{XT}:=\mathrm{X} 0+\mathrm{T} ; \mathrm{SX}:=\mathrm{S}+0.5-\mathrm{X} 0 ; \mathrm{W} 1:=\mathrm{W} 2:=0$;

$\mathrm{X} 1:=-0.5 ; \mathrm{X} 2:=0.5 ; \mathrm{Z} 1:=\mathrm{D} ; \mathrm{DELTA}:=1.0$; go to SIGMA; if $\mathrm{SX}-\mathrm{T} \geq 0$

then begin $\mathrm{X} 2:=\mathrm{XT}$; go SIGMA; LABEL : $=1$ end

else begin $\mathrm{X} 2:=\mathrm{S}+0.5$; go to SIGMA;

if $\mathrm{H}-\mathrm{Z} 0-R \geqq 0$

then LABEL : $=2$

else $U:=\operatorname{SQRT}(\mathrm{R} 2-(\mathrm{H}-\mathrm{Z} 0) \uparrow 2)$;

if $\mathrm{ABS}(\mathrm{SX})-\mathrm{U} \geqq 0$

then LABEL : $=2$

else $\mathrm{Z} 1:=\mathrm{H}$;

if $\mathrm{ABS}(\mathrm{SX}+\mathrm{L})-\mathrm{U} \geqq 0$

then begin $\mathrm{X} 2:=\mathrm{X} 0+\mathrm{U}$;

go to SIGMA;

LABEL : $=3$

end

else $\mathrm{X} 2:=\mathrm{S}+0.5+\mathrm{L}$;

go to SIGMA;

$\mathrm{X} 2:=\mathrm{X} \mathrm{T}$;

go to SIGMA;

end ;

LABEL : $=4$

end QCŌMP;

for $J:=-5.0$ step 1.0 until 5.0 do

begin $\mathrm{Z} 0:=\mathrm{ZM}+\mathrm{MESH}^{*} \mathrm{~J}$;

if $\mathrm{Z} 0>0$

then go to end

else for $I:=-5.0$ step 1.0 until 5.0 do

begin $\mathrm{X} 0:=\mathrm{XM}+\mathrm{MESH}{ }^{*} \mathrm{I}$;

if $\mathrm{X} 0 \leqq 0$

then go to end

else R $2:=(\mathrm{X} 0+0.5) \uparrow 2+(\mathrm{D}-\mathrm{Z} 0) \uparrow 2$;

$\mathrm{R}:=\mathrm{SQRT}(\mathrm{R} 2) ; \mathrm{T}:=\mathrm{SQRT}(\mathrm{R} 2-Z 0 \uparrow 2)$;

go to QCŌMP; go to MINIMUM

end

end

end LŌCATE;

IMPRŌV) begin if $\mathrm{K}=0$ then go to end end IMPRŌV;

else XM : =XQMIN; ZM : =ZQMIN; MESH : =MESH $/ 5.0 ;$ go to CYCLE

PRINT) begin CRLF; PRINTSTRING(Q); PRINTREAL(QMIN); PRINTSTRING(C);

PRINTINTEGER(LABMIN) ; PRINTSTRING()); PRINTSTRING(X0);

PRINTREAL(XQMIN); PRINTSTRING(Z0); PRINTREAL(ZQMIN)

end PRINT

end 


\section{近接した根切りによる地盤支持力の低下}

$\begin{array}{ccccc}\text { 正会員 } & \text { 大 } & \text { 崎 } & \text { 順 } & \text { 彦* } \\ \text { 准会員 } & \text { 原 } & & \text { 昭 } & \text { 夫** }\end{array}$

Fig. 1 に示したよらに,フーチングあるいは建物に近 接して根切りが行なわれた場合，その支持力は低下し， 低下の率は，フーチングまたは建物の幅 $B$, その根入れ 深さ $D$, 根切りまでの距離 $S$, その哚さ $H$ と幅 $L$ およ び地盤の単位体積重量 $r$, 粘着力 $c$, 内部摩擦角 $\phi$ などに よって影響されることは明らかである。この論文の目的 は，円弧スベリ面を仮定して，上記のよ5な諸数值が与 えられた場合，支持力が根切りのない状態に比較して，

* 建設省建築研究所主任研究員 $\cdot$ 工博

** 鹿島技術研究所研究員

（明和 40 年月 4 日 22 日本穗受理，教論期限昭和 40 年 12 月末日）
どの程度低下するかを計算する計数型電子計算機用プロ グラムを示すことにある。

円弧スベリ面の中心位置を，はじめは粗く，しだいに 精密に仮定しながら，最終的に支持力の極小值を与える スベリ面を見いだして行く技法は，既発表の論文「2層 地盤の支持力に関する一近似解法」（学会論文報告集, 第 99 号, 昭和 39 年 6 月) の場合と同一である。ただ しいまの場合は，根切り部分の規模と位置によって，ス ベリ面に Fig. 2 に示したような 4 種類の型がある。得 られたプログラムは，付録に Algol によって記してあ り，計算結果の一例を示したものが，Fig. 3 である。 
prestresses and rise of curved surface upon its natural frequencies is calculated numerically in the case of Hyperbolic Paraboloid surface and its vibrational behaviors are discussed from the qualitative point of view. According results, it is shown that seilnet behaviors in vibration are greatly influenced upon by the rise of a curved surface and that extentional deformations after prestressed are the most important factor in natural frequencies of a seilnet structure.

U.D.C. 624.131

\section{4) DECREASE OF BEARING CAPACITY DUE TO ADJACENT EXCAVA- TION (see page 19)}

by Dr. YORIHIKO OHSAKI, Building Research Institute, Ministry of Construction, Japanese Government, Member of A.I.J., AK1O HARA, Institute of Construction Technology, Kajima Construction Co., Member of A.I.J.

\section{U.D.C. $693.546: 72.011 .27$ \\ 5) 6) DISTRIBUTION OF CONSTRUCTION LOADS AND MINIMUM REMO- VAL PERIOD OF SHORES IN CONCRETE WORK OF MULTISTORY BUILDING (No. 1, No. 2)}

by MO'TOKI KONDO, Chief Research Engineer of Takenaka Building Research Institute. Member of A.I.J.

This report is regarding to thoretical analysis of loads distribution between reinforced concrete beam or slab and their shores during construction.

If level of $(k+3)$ story is concreted and each shores of $(k+2)$ level are subjected to the loads, load increments of shores in $(k+1)$ and $k$ level can be calculated by linear equations, provided the coefficient of displacement of beam or floor, which is defined as displacement at a point when a unit load is added at another point, is calculated previously.

Load decrements of shores in upper levels, which emerge on removal of shores in the lowest level, are also calculated by similar equations.

Construction loads sustained by shores in some story are accumulation of the above increments and decrements of loads during construction.

Conclusions of analysifs are as follows,

(1) Usually, theoretical constraction loads sustained by the lowest shores are not over $1.0 \sim 1.1$, that are expressed as load ratio to the load sustained by the uppermost shore. Then, the maximum load ratio of the lowest beam or slab is usually $2.0 \sim 2.1$, including dead load 1.0 .

(2) The above load ratio is hardly dependent on number of shored levels, rate of construction, positions of shores, stiffness ratio of beam and slab, deformation ratio of shore, and so others.

(3) Therefore, the safety factor in the lowest floor is mainly dependent on the design allowable load and the dead of floor concrete, that is, the thickness of slab in the uppermost level.

Relationship between construction load artio to the long time allowable load, the thickness of slab, and the live load for design is shown as Fig. 21.

(4) Construction loads, of which load ratio is over than 1.5 in Fig. 21, are over the short time allowable load inevitably. Then, in such a case the design allowable or the thickness of the slab must be modified in the design process.

(5) Construction loads, of which load ratio is less than 1.5 but over than 1.0 in Fig. 21, are over the long time allowable load inevitably, but not over the short time allowable load. In such a case, minimum removal period of shores under slabs can be estimated graphically in Fig. 22-24.

(6) The case, that construction loads are less than 1.0 in Fig. 21, do not appear in usual design.

(7) The allowable load for beam design in Japanese Building Code, which is less than that for slab design, must be revised, because construction loads are severely over the allowable load for beam during construction.

U.D.C. 72.021 .22

\section{7) TIME STUDY OF ARCHITECTURAL DESIGN - 2 -}

by TOSHIHIKo OTA, Research Laboratory of Shimizu Construction Company, Member of A.I.J.

Generally, the most architectursl design system has been only experiential and individual, however, by surveying the actual working procedure of design we should be able to get the points of design technique, by which 